\title{
Analisis Aspek Permodalan Pada Koperasi Multi Kharisma Banyuasin
}

\author{
Totok Sudiyanto \\ Akuntansi, Fakultas Ekonomi Universitas PGRI Palembang \\ totoktajir78@univpgri-palembang.ac.id
}

\begin{abstract}
This study aims to determine and analyze the performance of Capital Aspects in the Banyuasin Multi Kharisma Cooperative in 2014-2018. In this case the financial statements are important as a benchmark and as providers of financial information in evaluating the performance of the capital aspects, if the capital aspects are assessed in a bad condition then it can be assessed as a whole that the cooperative capital is in an unhealthy condition or is below standard. In this study, the data used are secondary data, with data collection methods in the form of documentation and study of literature, as well as using qualitative research methods, while data analysis techniques use descriptive qualitative techniques, where the data needed is analyzed and then the results of the analysis are described in written form. The results of research and discussion conducted on aspects of capital in the Banyuasin Multi Kharisma Cooperative in 2014-2018 are in the healthy category. The author suggests to maintain and maintain the overall value of cooperative capital so that the value of cooperative capital remains greater than the total amount of total assets and total risk loans provided by cooperatives.
\end{abstract}

Keywords: financial statements and performance aspects of capital

\section{ABSTRAK}

Penelitian ini bertujuan untuk mengetahui dan menganalisis kinerja Aspek Permodalan pada Koperasi Multi Kharisma Banyuasin tahun 2014-2018. Dalam hal ini laporan keuangan merupakan hal penting sebagai tolak ukur dan sebagai pemberi informasi keuangan dalam penilaian kinerja aspek permodalan, apabila aspek permodalan dinilai dalam keadaan buruk maka dapat dinilai secara keseluruhan bahwa permodalan koperasi sedang berada dalam kondisi yang tidak sehat atau di bawah standar. Dalam penelitian ini, data yang digunakan adalah data sekunder, dengan metode pengumpulan data berupa dokumentasi dan studi kepustakaan, serta menggunakan metode penelitian kualitatif,sedangkan teknik analisis data menggunakan teknik deskriptif kualitatif, dimana data yang diperlukan di analisis lalu kemudian hasil analisis tersebut di deskripsikan dalam bentuk tulisan. Hasil penelitian dan pembahasan yang di lakukan terhadap aspek permodalan pada Koperasi Multi Kharisma Banyuasin pada tahun 2014-2018 berada dalam kategori sehat. Penulis menyarankan untuk tetap mempertahankan dan menjaga keseluruhan nilai modal koperasi agar nilai modal koperasi tetap lebih besar dari jumlah keseluruhan total aset maupun total pinjaman berisiko yang diberikan oleh koperasi.

Kata Kunci : laporan keuangan dan kinerja aspek permodalan

\section{A. Pendahuluan}

Indonesia merupakan negara dengan jumlah penduduk terpadat ke empat di dunia. Hal ini dikarenakan angka kelahiran yang begitu tinggi disetiap tahunnya. Namun angka kelahiran yang tinggi ini tidak diiringi dengan berkembangnya infrastruktur publik yang memadai. Hal ini menyebabkan Indonesia masuk ke dalam kategori negara berkembang dikarenakan pemerintahnya yang terus membangun segala sarana dan prasarana tanpa henti. 
Meski dikategorikan sebagai negara berkembang, Indonesia memiliki sumber daya manusia yang tak kalah dengan negara maju. Meningkatnya kesadaran masyarakat Indonesia akan pentingnya pendidikan telah membuat Indonesia memiliki sumber daya manusia yang dapat berdaya saing,sejajar dengan negara maju. Namun dikarenakan pembangunan daerah yang tidak merata dan rumitnya birokrasi membuat sumber daya manusia di Indonesia sulit untuk mengembangkan diri. Sehingga menyebabkan masih banyaknya penduduk yang bependidikan tinggi namun tidak memiliki pekerjaan.

Hal ini dikarenakan mereka lebih banyak memiliki pola pikir untuk mencari pekerjaan daripada menciptakan lapangan pekerjaaan. Pola pikir yang demikian secara tidak langsung telah membuat Indonesia masih berada dalam garis kemiskinan dan membuat kondisi perekonomian di Indonesia tidak mengalami perkembangan yang signifikan dari tahun ke tahun.

Jumlah pencari kerja yang lebih tinggi daripada tersedianya lapangan pekerjan membuat angka pengangguran di Indonesia semakin meningkat setiap tahunnya. Meski demikian tidak semua penduduk di Indonesia memiliki pola pikir untuk mencari pekerjaan, masih ada pula sebagian besar penduduk di Indonesia yang justru menciptakan lapangan pekerjaan untuk dirinya dan juga disekitarnya dan karenanya secara tidak langsung masalah pengangguran di Indonesia dapat teratasi dan membuat perekonomian Indonesia cenderung stabil bahkan gerakan ini telah membuat roda perekonomian Indonesia meningkat menjadi sedikit lebih baik. Namun terciptanya lapangan pekerjan ini biasanya terkendala terhadap modal yang diperlukan, serta masih sulitnya para pengusaha dalam memasarkan produk mereka agar produk mereka dapat dikenal dan diterima oleh masyarakat.

Menurut undang-undang No.25 tahun 1992, koperasi adalah badan usaha yang beranggotakan orang-orang atau badan hukum koperasi dengan melandaskan kegiatannya berdasarkan prinsip koperasi sekaligus sebagai gerakan ekonomi rakyat yang berdasarkan asas-asas kekeluargaan.

Koperasi juga merupakan lembaga yang sangat dibutuhkan oleh masyarakat saat ini guna membangun perekonomian agar menjadi lebih baik, karena koperasi adalah gerakan ekonomi rakyat yang berdiri atas dasar kekeluargaan dengan tujuan untuk mensejahterakan para anggotanya. Dan juga koperasi merupakan badan usaha yang mengorganisir pemanfaatan dan pendayagunaan sumber daya ekonomi para anggotanya. Sehingga dengan demikian dapat dikatakan bahwa koperasi merupakan gerakan ekonomi rakyat dan soko guru perekonomian nasional di Indonesia, yang secara tidak langsung juga telah membuat perekonomiaan di Indonesia terus berkembang menjadi lebih baik di setiap tahunnya.

Koperasi Multi Kharisma Banyuasin, merupakan koperasi serba usaha yang bergerak di segala bidang. Termasuk salah satu didalamnya adalah bidang usaha jasa yaitu, berupa jasa simpan pinjam yang menyediakan dana yang relatif mudah dan ringan bagi anggotanya, jasa dalam bidang penyediaan lapangan pekerjaan bagi masyarakat umum yang membutuhkan pekerjaan, dan koperasi ini juga bergerak dalam bidang jasa pembayaran sewa menyewa/pendanaan untuk berbagai keperluan yang digunakan dalam proses usaha khusunya di bidang pertambangan.

Sebagaimana badan usaha pada umumnya koperasi memerlukan alat untuk menilai kinerja keuangannya guna mempertahankan kelangsungan hidup dan juga sebagai bahan evaluasi bagi para pemakai jasa koperasi baik itu untuk pihak manajemen, investor maupun pihak terkait lainnya, dan untuk menilai kinerja 
keuangan biasanya digunakan rasio sebagai tolak ukur untuk membandingkan beberapa laporan keuangan dari beberapa periode yang telah terjadi. Dengan menggunakan laporan keuangan tersebut dapat diketahui tingkat perbandingan berbagai rasio yang dapat diolah guna kepentingan dan kemajuan suatu badan usaha.

Berikut Neraca Koperasi Multi Kharisma Banyuasin periode 2014-2018 adalah sebagai berikut :

Tabel 1

Neraca Koperasi Karya Mukti

Periode 2014-2018

(dalam Rp)

\begin{tabular}{|c|c|c|r|}
\hline \multirow{2}{*}{ TAHUN } & \multicolumn{3}{|c|}{ Akun } \\
\cline { 2 - 4 } & Total Aset & Total Liabilitas & \multicolumn{1}{c|}{ Total Ekuitas } \\
\hline 2014 & $13.084 .652 .090,25$ & $2.896 .564 .977,61$ & $10.188 .087 .112,64$ \\
\hline 2015 & $14.437 .250 .669,51$ & $5.864 .633 .209,37$ & $8.284 .167 .715,14$ \\
\hline 2016 & $14.293 .510 .527,65$ & $3.498 .713 .067,31$ & $10.266 .936 .963,34$ \\
\hline 2017 & $15.015 .684 .615,59$ & $1.874 .460 .788,28$ & $13.141 .223 .827,31$ \\
\hline 2018 & $15.528 .075 .431,36$ & $1.734 .700 .877,28$ & $13.793 .374 .554,08$ \\
\hline
\end{tabular}

Sumber : Koperasi Multi Kharisma Banyuasin yang diolah

Dari tabel diatas dapat dilhat bahwa struktur aset secara keseluruhan sangat baik, dimana ini dibuktikan pada tahun 2017 menuju ke 2018 total aset mengalami peningkatan sebesar Rp 512.390.815,77 yang membuat total aset pada tahun 2018 memiliki nilai tertinggi jika dibandingkan dengan tahun sebelumnya. Meski pada tahun 2017 total aset sedikit mengalami penurunan, namun total aset pada tahun ini secara keseluruhan masih tetap lebih besar dari total liabilitasnya. Walaupun mengalami kenaikan dan penurunan dalam struktur asetnya, namun secara keseluruhan total aset yang dimiliki oleh koperasi ini masih dapat dikelompokkan dalam kategori yang cukup baik, hal ini dikarenakan total aset yang dimiliki koperasi selama lima tahun terakhir masih lebih besar daripada total liabilitasnya.

Untuk struktur modal atau ekuitas Koperasi Multi Kharisma Banyuasin secara keseluruhan selama tahun 2013-2017 berada dalam kategori baik karena total ekuitasnya masih lebih besar daripada total liabilitasnya.

Namun jika dilihat dari tahun 2014-2018 antara total aset, total liabilitas dan total ekuitas koperasi ini mengalami fluktuasi, terjadi sedikit kenaikan namun tak sedikit pula terjadi penurunan, karena kenaikan dan penurunan ini maka kinerja aspek permodalan koperasi belum dapat untuk dilakukan.

Pengukuran kinerja permodalan sendiri sangat berguna bagi badan usaha guna membandingkan badan usaha lainnya yang sejenis sehingga apabila suatu saat terjadi sebuah kekeliruan maka hasil dari pengukuran kinerja ini dapat dijadikan sebagai bahan pertimbangan mengenai tindakan apa yang perlu dilakukan guna memperbaiki kekeliruan tersebut. 


\section{B. Kajian Teori \\ Kinerja Keuangan}

\section{1) Pengertian Kinerja Keuangan}

Menurut IAI dalam SAK ETAP (2013:6) kinerja keuangan adalah hubungan antara penghasilan dan beban dari entitas sebagaimana disajikan dalam laporan laba rugi. Laba sering digunakan sebagai ukuran kinerja atau sebagai dasar untuk pengukuran lain seperti tingkat pengembalian investasi atau laba per saham.

Menurut Fahmi (2012:2) kinerja keuangan merupakan suatu analisis yang dilakukan untuk melihat sejauh mana suatu perusahaan telah melaksanakan dengan menggunakan aturan-aturan pelaksanaan keuangan secara baik dan benar. Seperti dengan membuat suatu laporan keuangan yang telah memenuhi standar dan ketentuan SAK (Standar Akuntansi Keuangan) atau GAAP (General Accepted Accounting Principle) dan lainnya.

Pengukuran kinerja keuangan adalah penting sebagai sarana atau indikator dalam rangka memperbaiki kegiatan operasional perusahaan, dengan perbaikan kinerja operasional diharapkan bahwa perusahaan dapat mengalami pertumbuhan keuangan yang lebih baik dan juga dapat bersaing dengan perusahaan lain lewat efisisensi dan efektivitas.

\section{2) Teknik Analisis Kinerja Keuangan}

Kinerja Keuangan dapat dinilai dengan menggunakan beberapa teknik analisis. Menurut Hery (2015:29), teknik analisis kinerja keuangan dapat dibedakan menjadi 9 macam, yaitu :

a) Analisis Perbandingan Laporan Keuangan, merupakan teknik analisis dengan cara membandingkan laporan keuangan dari dua periode atau lebih untuk menunjukkan perubahan dalam jumlah absolut maupun dalam persentase.

b) Analisis Tren, merupakan teknik analisis yang digunakan untuk mengetahui tedensi keadaan keuangan dan kinerja perusahaan, apakah menujukkan kenaikan atau penurunan.

c) Analisis persentase per komponen (common size), merupakan teknik analisis yang digunakan untuk mengetahui persentase masing-masing komponen aset terhadap total aset; persentase masing-masing komponen utang dan modal terhadap total passiva (total aset); persentase masing masing komponen laporan laba rugi terhadap penjualan bersih.

d) Analisis Sumber dan Penggunaan Modal Kerja, merupakan teknik analisis yang digunkan untuk mengetahui besarnya sumber dan penggunaan modal kerja selama dua periode yang diperbandingkan.

e) Analisis Sumber dan Penggunaan Kas, merupakan teknik analisis yang digunakan untuk mengetahui kondisi kas dan perubahan kas pada suatu periode waktu tertentu.

f) Analisis Rasio Keuangan, merupakan teknik analisis yang digunakan untuk mengetahui hubungan diantara pos tertentu dalam neraca maupun laporan laba rugi.

g) Analisis Perubahan Laba Kotor, merupakan teknik analisis yang digunakan untuk mengetahui posisi laba kotor dari suatu periode ke periode berikutnya, serta sebab-sebab terjadinya perubahan laba kotor tersebut. 
h) Analisis Titik Impas, merupakan teknik analisis yang digunakan untuk mengetahui tingkat penjualan yang harus dicapai agar perusahaan tidak mengalami kerugian.

i) Analsisis Kredit, merupakan teknik analisis yang digunakan untuk menilai layak atau tidaknya suatu permohonan kredit debitur kepada kreditur, seperti bank.

\section{3) Metode Penilaian Kinerja Keuangan}

Metode penilaian kinerja keuangan dapat dilakukan dengan berbagai macam metode. Pemilihan metode yang digunakan disesuaikan dengan tujuan dilakukannya penelitian terhadap kinerja keuangan tersebut.

Menurut Jumingan (2014:242) metode yang dapat digunakan adalah dengan analisis perbandingan laporan keuangan, analisis tren, analisis common size statement, analisis penggunaan modal, analisis penggunaan kas, analisis rasio keuangan, gross profit analysis dan analisis break even point.

\section{4) Pengertian Laporan Keuangan.}

Menurut Kasmir (2012:7) laporan keuangan adalah laporan yang menunjukkan kondisi keuangan perusahaan pada saat ini atau dalam periode tertentu.

Menurut Munawir (2014:2) laporan keuangan lah hasil dari proses akuntansi yang dapat digunakan sebagai alat ukur untuk berkomunikasi antar data keuangan atau aktivitas suatu perusahaaan dengan pihak-pihak yang berkepentingan dengan data atau aktivitas perusahaan tersebut.

Jadi dapat disimpulkan bahwa laporan keuangan merupakan sumber informasi yang sangat penting, dikatakan sangat penting karena laporan keuangan memberikan informasi yang dibutuhkan olehpihak -pihak yang berkepentingan yang berguna dalam proses pengambilan keputusan. Selain itu laporan keuangan juga dibutuhkan guna menilai kinerja keuangan suatu perusahaan baik profit maupun non profit di setiap tahunnya.

\section{5) Jenis Laporan Keuangan}

Menurut IAI dalam SAK ETAP (2013:17) terdapat lima jenis laporan keuangan yaitu :

a) Neraca;

b) Laporan Laba Rugi;

c) Laporan perubahan ekuitas yang menunjukkan:

$>$ Seluruh perubahan dalam ekuitas, atau

$>$ Perubahan ekuitas selain perubahan yang timbul dari transaksi dengan pemilik dalam kapasitasnya sebagai pemilik;

d) Laporan Arus Kas dan ;

e) Catatan atas laporan keuangan yang berisi ringkasan kebijakan akuntansi yang signifikan dan informasi penjelasan lainnya.

6) Karakteristik Laporan Keuangan.

Laporan keuangan koperasi memiliki karakteristik tersendiri dalam laporan keuangan terutama pada neraca dan laporan rugi laba. Berdasarkan PERMENKUKM RI No.4/Per/M.KUKM/VII/2012 tentang Pedoman Umum Akuntansi Koperasi adalah berikut merupakan karakteristik spesifik dari laporan keuangan koperasi yaitu : 
a) Laporan keuangan merupakan bagian dari laporan pertanggung jawaban pengurus selama satu periode akuntansi yang dapat dipakai sebagai bahan untuk menilai hasil kerja pengelolaan koperasi.

b) Laporan keuangan koperasi merupakan bagian dari sistem pelaporan koperasi yang ditujukan untuk pihak internal maupun eksternal koperasi.

c) Laporan keuangan koperasi harus berdayaguna bagi para anggotanya, sehingga pihak anggota dapat menilai manfaat ekonomi yang diberikan koperasi dan berguna juga untuk mengetahui :

1. Prestasi unit kegiatan koperasi yang secara khusus bertugas memberikan pelayanan kepada para anggotanya selama satu periode akuntansi tertentu;

2. Prestasi unit kegiatan koperasi secara khusus ditujukan untuk tujuan bisnis dengan non anggota selama satu periode akuntansi tertentu;

3. Informasi penting lainnya yang memengaruhi keadaan keuangan koperasi jangka pendek dan jangka panjang.

\section{7) Tujuan Laporan Keuangan}

Menurut Kasmir (2014:11) Tujuan Penyusunan Laporan Keuangan yaitu:

a) Memberikan informasi tentang jenis dan jumlahaktiva (harta) yang dimiliki perusahaan pada saat ini.

b) Memberikan informasi tentang jenis dan jumlah kewajiban dan modal yang dimiliki perusahaan pada saat ini.

c) Memberikan informasi tentang jenis dan jumlah pendapatan yang diperoleh pada suatu periode tertentu.

d) Memberikan informasi tentang jumlah biaya dan jenis biaya yang dikeluarkan perusahaan dalam suatu periode tertentu

e) Memberikan informasi tentang perubahan-perubahan yang terjadi terhadap aset, passiva dan modal perusahaan.

f) Memberikan informasi tentang kinerja manajemen perusahaan dalam suatu periode.

g) Memberikan informasi tentang catatan-catatan atas laporan keuangan.

h) Informasi keuangan lainnya.

Dapat pula dikatakan bahwa tujuan laporan keuangan adalah untuk memberikan informasi kepada pihak-pihak terkait yang membutuhkan informasi terhadap kondisi keuangan suatu perusahaan.

\section{Analisis Laporan Keuangan}

Menurut Sjahrial dan Purba (2013:1), analisis laporan keuangan adalah aplikasi dari alat dan teknik analisis untuk laporan keuangan yang bertujuan umum dan datadata yang berkaitan untuk menghasilkan estimasi dan kesimpulan yang bermanfaat dalam analisis bisnis

Menurut Munawir (2010:35), analisis laporan keuangan adalah analisis laporan keuangan yang terdiri dari penelaahan atau mempelajari hubungan yang tedensi atau kecendrungan untuk menentukan posisi keuangan dan hasil operasi serta perkembangan perusahaan yang bersangkutan.

Analisis laporan keuangan merupakan metode yang membantu para pengambil keputusan untuk mengetahui kekuatan dan kelemahan perusahaan melalui informasi yang didapat dari laporan keuangan. Analisis laporan keuangan dapat membantu 
manajemen untuk mengidentifikasi kekurangan atau kelemahan yang ada dan kemudian membuat keputusan.

\section{1) Tujuan dan Manfaat Analisis Laporan Keuangan}

Menurut Hery (2015:133) tujuan dan manfaat dari dilakukannya analisis laporan keuangan secara umum, adalah :

a) Untuk mengetahui posisi keuangan perusahaan dalam satu periodetertentu, baik aset, liabilitas, ekuitas, maupun hasil usaha yang telah dicapai selama beberapa periode.

b) Untuk mengetahui kelemahan-kelemahan yang menjadi kekurangan perusahaan.

c) Untuk mengetahui kekuatan-kekuatan yang menjadi keunggulan perusahaan

d) Untuk menentukan langkah-langkah perbaikan yang perlu dilakukan dimasa mendatang, khususnya yang berkaitan dengan posisi keuangan peusahaan saat ini.

e) Untuk melakukan penilaian kinerja keuangan manajemen.

f) Sebagai pembanding dengan perusahaan sejenis, terutama mengenai hasil yang telah dicapai.

\section{2) Analisis Rasio Keuangan}

Menurut Hery (2015:163) analisis rasio adalah analisis yang dilakukan dengan menghubungkan berbagai perkiraan yang ada pada laporan keuangan dalam bentuk rasio keuangan.

Menurut Horne (2012:104) analisis rasio keuangan merupakan indeks yang menghubungkan dua angka akuntansi dan diperoleh dengan membagi satu angka dengan angka lainnya. Rasio keuangan digunakan untuk mengevaluasi kondisi keuangan dan kinerja perusahaan.

Analisis Rasio Keuangan dapat mengungkapkan hubungan yang penting antar perkiraan laporan keuangan dan dapat digunakan untuk mengevaluasi kondisi keuangan dan kinerja perusahaan

\section{3) Keunggulan Analisis Rasio Keuangan}

Menurut Hery (2015:164), analisis rasio keuangan memiliki beberapa keunggulan yaitu :

- Rasio merupakan angka-angka atau ikhtisar statistik yang lebih mudah dibaca dan ditafsirkan.

- Rasio merupakan pengganti yang cukup sederhana dari informasi yang disajikan dalam laporan keuangan yang pada dasarnya sangat rinci dan rumit.

- Rasio dapat mengidentifikasi posisi perusahaan dalam industri.

- Rasio sangat beranfaat dalam pengambilan keputusan.

- Dengan rasio lebih mudah untuk membandingkan suatu perusahaan terhadap perusahaan lain atau melihat perkembangan perusahaan secara periodik (time series).

- Dengan rasio lebih mudah untuk melihat tren perusahaan serta melakukan prediksi untuk dimasa yang akan datang.

4) Kelemahan Analisis Rasio Keuangan 
Menurut Fahmi (2012:48), ada beberapa kelemahan dengan dipergunakannya rasio keuangan yaitu :

- Penggunaan rasio keuangan akan memberikan pengukuran yang relatif terhadap kondisi suatu perusahaan.

- Analisis rasio keuangan hanya dapat dijadikan sebagai peringatan awal dan bukan kesimpulan akhir.

- Setiap data yang diperoleh dipergunakan dalam menganalisis adalah bersumber dari laporan keuangan perusahaan, maka sangat memungkinkan data yang diperoleh tersebut adalah data yang angka- angkanya tidak memiliki keakuratan yang tinggi, dengan alasan mungkin saja data dat tersebut diubah dan disesuaikan berdasarkan kebutuhan

- Pengukuran rasio keuangan banyak bersifat artificial, yang artinya perhitungan tersebut dilakukan oleh manusia, dan setiap pihak memiliki pandangan yang berbeda beda dalam menempatkan ukuran dan terutama justifikasi dipergunakannya rasio rasio tersebut.

\section{Tingkat Kesehatan Koperasi}

Berdasarkan Peraturan Menteri Koperasi Usaha Kecil dan Menengah No.20/Per/M.KUKM/XI/2008 dijelaskan bahwa ruang lingkup penilaian kinerja kesehatan koperasi dapat dinilai dari beberapa aspek, yaitu :

1. Aspek Permodalan, terdiri dari :

a) Rasio Modal Sendiri terhadap Total Aset

b) Rasio Modal Sendiri terhadap Pinjaman Berisiko

c) Rasio kecukupan Modal Sendiri

2. Aspek Kualitas Aset Produktif, terdiri dari :

a) Rasio Volume Pinjaman Para Anggota terhadap Volume Pinjaman yang diberikan.

b) Rasio Risiko Pinjaman Bermasalah terhadap Volume Pinjaman.

c) Rasio Cadangan Risiko terhadap Pinjaman Bermasalah

d) Rasio BMPP terhadap calon anggota, koperasi lain dan anggotanya terhadap Volume Pinjaman.

3. Aspek Manajemen, terdiri dari :

a) Manajemen Umum

b) Manajemen Kelembagaan

c) Manajemen Permodalan

d) Manajemen Aset

e) Manajemen Likuiditas

4. Aspek Efisiensi, terdiri dari :

a) Rasio Biaya Operasional Pelayanan terhadap Partisipasi Bruto

b) Rasio Aset Tetap Terhadap Total Aset

c) Rasio Efisiensi Pelayanan

5. Aspek Likuiditas, terdiri dari :

a) Rasio Kas

b) Rasio Volume Pinjaman terhadap Dana yang diterima

6. Aspek Kemandirian dan Pertumbuhan, terdiri dari :

a) Rasio Rentabilitas terhadap Aset 
b) Rasio Rentabilitas terhadap Modal Sendiri

c) Rasio Kemandirian terhadap Operasional Pelayanan

7. Aspek Jati Diri Koperasi, terdiri dari :

a) Rasio Partisipasi Bruto

b) Rasio Promosi Ekonomi Anggota

\section{Modal Koperasi}

Modal Kerja menurut Jumingan (2011:6) yaitu jumlah dari aset lancar. Defnisi ini bersifat kuantitatif karena menunjukkan jumlah dana yang digunakan untuk maksud operasi-operasi jangka pendek. Waktu tersedianya modal akan tergantung pada macam dan tingkat likuiditas dari unsur-unsur aset lancar misalnya kas, suratsurat berharga, piutang dan persediaan.

Sedangkan Modal Kerja menurut Kasmir (2012:205) merupakan modal yang digunakan untuk melakukan kegiatan operasi perusahaan. Modal diartikan sebagai investasi yang ditanamkan dalam aset lancar atau aset jangka pendek seperti kas, surat-surat berharga, piutang, persediaan dan aset lancar.

Menurut Turi (2014:15) modal kerja koperasi bersumber dari para anggota, modal penyertaan dan sumbangan baik dari anggota, pemerintah maupun swasta, simpanan pokok, simpanan wajib dan simpanan lainnya yang memiliki karakteristik serupa dengan simpanan pokok atau simpanan wajib diakui sebagai ekuitas koperasi dan dicatat sebagai nilai nominalnya.

\section{$>\quad$ Rasio Aspek Permodalan Koperasi}

Rasio aspek permodalan koperasi digunakan untuk mengetahui seberapa besar tingkat perputaran modal koperasi baik terhadap total asetnya, pinjaman yang berisiko maupun perputaran modal koperasi terhadap kecukupan modal yang dimilikinya. Berikut merupakan rumus rasio aspek permodalan koperasi berdasarkan PERMENKUKMNO20/PER/M.KUKM/XI/2008 :

Rasio Modal Sendiri terhadap Aset

$$
=\frac{\text { Modal Sendiri }}{\text { Total Aset }} \times 100 \%
$$

Rasio Modal Sendiri terhadap Pinjaman Berisiko

$$
=\frac{\text { Modal Sendiri }}{\text { Pinjaman diberikan berisiko }} x 100 \%
$$

Rasio Kecukupn Modal Sendiri terhadap ATMR

$$
=\frac{\text { Modal Sendiri }}{A T M R} \times 100 \%
$$

\section{Metode Penelitian}

Menurut Sugiyono (2010:8) penelitian kualitatif adalahpenelitian yang digunakan unuk meneliti objek yang bersifat alamiah dimana peneliti adalah sebagai instrumen kunci, teknik pengumpulan data dilakukan secara trigulasi (gabungan), analisis data bersifat induktif/kualitatif dan hasil penelitian kualitatif lebih menekankan makna 
daripada generalisasi. Metode yang digunakan dalam penelitian ini adalah metode kualitatif.

\section{Populasi dan Sampel}

1) Populasi Peneltian

Menurut Sugiyono (2013:115) populasi adalah wilayah generalisasi yang terdiri dari atas objek dan subjek yang mempunyai kualitas dan karakteristik tertentu yang ditetapkan oleh peneliti untuk dipelajari dan kemudian ditarik kesimpulannya.

Populasi dalam penelitian ini adalah berupa Neraca Koperasi Multi Kharisma Banyuasin tahun 2014-2018

\section{2) Sampel}

Menurut Sugiyono (2013:116) sampel adalah bagian dari jumlah karakteristik yang dimiliki oleh populasi tersebut.

Sampel dalam penelitian ini adalah berupa Neraca Koperasi Multi Kharisma Banyuasin tahun 2014-2018.

\section{E. Teknik Pengumpulan Data}

\section{1) Sumber Data}

Sumber data yang digunakan pada penelitian ini adalah berupa data sekunder. Menurut Sugiyono (2012:137) data sekunder adalah sumber data yang secara tidak langsung memberikan data kepada pengumpul data, misalnya melalui orang lain atau dokumen.

\section{2) Metode Pengumpulan Data}

Metode pengumpulan data dalam penelitian ini adalah berupa dokumentasi dan studi kepustakaan.

Menurut Sugiyono (2015:329) dokumentasi adalah suatu cara yang digunakan untuk memperoleh data dan informasi dalam bentuk buku, arsip, dokumen, tulisan angka dan gambar yang berupa laporan, serta keterangan yang dapat mendukung penelitian.

Menurut Sugiyono (2012:137) studi kepustakaan adalah kajian teoritis, referensi serta literatur ilmiah lainnya yang berkaitan dengan budaya, nilai dan norma yang berkembang pada situasi sosial yang diteliti.

\section{F. Teknik Analisis Data}

Menurut Sugiyono (2013:426) teknik analisis data digunakan untuk menjawab rumusan masalah.

Teknik analisis data yang digunakan pada penelitian ini adalah menggunakan teknik deskriptif kualitatif, dimana pada penelitian ini penulis melakukan penelitian dengan cara menganalisis data yang diperlukan lalu kemudian hasil analisis data tersebut dideskripsikan dalam bentuk tulisan.

\section{G. Hasil Penelitian}

1) Laporan Keuangan Koperasi Koperasi Multi Kharisma Banyuasin 
Laporan keuangan merupakan hal yang penting bagi setiap organisasi karena dengan adanya laporan keuangan dapat memberikan gambaran kepada pihak pihak yang berkepentingan mengenai kinerja keuangan dan perkembangan perusahaan. Selain itu juga laporan keuangan dapat memberikan gambaran kepada pihak manajemen dalam proses pengambilan keputusan.Dengan menganalisis laporan keuangan, dapat dilihat apakah perusahaan tersebut berjalan dan berkembang dengan baik ataukah tidak mengalami perkembangan sama sekali.

\section{2) Analisis Data}

> Analisis Rasio Modal Sendiri Terhadap Total Aset.

Rasio modal sendiri terhadap total aset digunakan untuk menggambarkan kemampuan modal perusahaan dalam memenuhi total aset yang dimilikinya. Untuk menganalisis rasio modal sendiri terhadap total aset dapat menggunakan rumus :

$$
\text { Rasio Modal Sendiri terhadap Total Aset }=\frac{\text { Modal Sendiri }}{\text { Total Aset }} \times 100 \%
$$

Berikut merupakan hasil analisis rasio modal sendiri terhadap total aset pada Koperasi Multi Kharisma Banyuasin:

1. Tahun 2014

$$
\begin{aligned}
& \frac{10.188 .087 .112,64}{13.084 .652 .090,25} \times 100 \% \\
& =0.7786=77,86 \%
\end{aligned}
$$

2. Tahun 2015

$$
\begin{aligned}
& \frac{8.284 .167 .715,14}{14.437 .250 .669,51} \times 100 \% \\
& =0,5738=57,38 \%
\end{aligned}
$$

3. Tahun 2016

$$
\begin{aligned}
& \frac{10.066 .936 .963,34}{14.293 .510 .527,65} \times 100 \% \\
& =0.7043=70,43 \%
\end{aligned}
$$

4. Tahun 2017

$$
\begin{aligned}
& \frac{13.141 .223 .827,31}{15.015 .684 .615,59} \times 100 \% \\
& =0,8751=87,51 \%
\end{aligned}
$$

5. Tahun 2018

$$
\begin{aligned}
& \frac{13.793 .374 .554,08}{15.528 .075 .431,36} \times 100 \% \\
& =0.8882=88,82 \%
\end{aligned}
$$

Berdasarkan hasil analisis diatas dapat dilihat bahwa rasio modal sendiri terhadap total aset pada Koperasi Multi Kharisma Banyuasin tahun 2014-2018 adalah sebagai berikut: 
1. Pada tahun 2014 rasio modal sendiri terhadap total aset koperasi di dapati hasil yaitu sebesar $77,86 \%$ yang diperoleh dari perhitungan modal sendiri sebesar Rp 10.188.087.112,64 dengan perhitungan total aset yaitu sebesar $\mathrm{Rp}$ 13.084.652.090,25. Hal ini berarti setiap 1 rupiah total aset dapat dijamin oleh modal sendiri sebesar 0,7786 rupiah atau $1: 0,7786$ antara modal sendiri dan total aset.

2. Pada tahun 2015 rasio modal sendiri terhadap total aset koperasi mengalami penurunan sebesar $20,48 \%$ dari $77,86 \%$ menjadi sebesar 57,38 \%. Hal ini dikarenakan total modal sendiri mengalami penurunan dari tahun sebelumnya. Angka rasio ini diperoleh dari hasil perhitungan modal sendiri sebesar $\mathrm{Rp}$ 8.284.167.715,14 terhadap total aset sebesar Rp 14.437.250.669,51. Hal ini berarti setiap 1 rupiah total aset dapat dijamin oleh modal sendiri sebesar 0,5738 rupiah atau $1: 0,5738$ antara modal sendiri dan total aset.

3. Pada tahun 2016 rasio modal sendiri terhadap total aset koperasi mengalami kenaikan yaitu sebesar $13,05 \%$ dari $57,38 \%$ menjadi sebesar $70,43 \%$ yang di peroleh dari perhitungan modal sendiri yaitu sebesar Rp 10.066.936.963,34 dengan total aset yaitu sebesar Rp 14.293.510.527,66. Hal ini berarti setiap 1 rupiah total aset dapat dijamin oleh modal sendiri sebesar 0,7433 rupiah atau 1 : 0,7433 antara modal sendiri dan total aset.

4. Pada tahun 2017 rasio modal sendiri terhadap total aset koperasi kembali mengalami kenaikan yaitu sebesar $17,08 \%$ dari $70,43 \%$ menjadi $87,51 \%$ yang diperoleh dari perhitungan modal sendiri sebesar $\mathrm{Rp} 13.141 .223 .827,31$ dengan total aset yaitu sebesar Rp 15.015.684.615,59. Hal ini berarti setiap 1 rupiah total aset dapat dijamin oleh modal sendiri sebesar 0,8751 rupiah atau 1 : 0,8751 antara modal sendiri dan total aset.

5. Pada tahun 2018 rasio modal sendiri terhadap total aset koperasi mengalami peningkatan yaitu sebesar $1,31 \%$ dari $87,51 \%$ menjadi $88,82 \%$ yang diperoleh dari perhitungan modal sendiri sebesar Rp 13.793.374.554,08 dengan total aset sebesar Rp 15.528.075.431,36. Hal ini berarti setiap 1 rupiah total aset dapat dijamin oleh modal sendiri sebesar 0,8882 rupiah atau $1: 0,8882$ antara modal sendiri dan total aset.

Berikut adalah standar penetapan rasio modal sendiri terhadap total aset :

Tabel 2

Standar Penetapan Rasio Modal Sendiri terhadap Total Aset

\begin{tabular}{|c|c|c|c|}
\hline $\begin{array}{c}\text { Rasio Modal } \\
(\%)\end{array}$ & Nilai & $\begin{array}{c}\text { Bobot } \\
(\%)\end{array}$ & Skor \\
\hline$\leq 0$ & 0 & 6 & 0 \\
$0<x \leq 5$ & 25 & 6 & 1.50 \\
$5<x \leq 10$ & 50 & 6 & 3.00 \\
$10<x \leq 15$ & 75 & 6 & 4.50 \\
$15<x \leq 20$ & 100 & 6 & 6.00 \\
\hline
\end{tabular}

Sumber : PERMENKUKMNO.20/PER/M.KUKM/XI/2008

Berdasarkan hasil analisis rasio modal sendiri terhadap total aset koperasi apabila dilihat dari perkembangannya dari tahun 2014-2018, rasio modal sendiri terhadap total aset tertinggi berada pada tahun 2018 dengan perolehan angka rasio 
sebesar $88,82 \%$, dan secara keseluruhan rata-rata rasio selama lima tahun terakhir mendapatkan angka rasio lebih dari $20 \%$. Hal ini sesuai dengan standar perhitungan rasio modal sendiri terhadap total aset dimana rasio modal yang mendapatkan hasil perhitungan lebih dari 20\%, maka akan mendapatkan nilai 100 dan memeroleh angka skor 6,00 sebagai nilai skor akhir nya.

\section{A Analisis Rasio Modal Sendiri Terhadap Pinjaman yang Berisiko}

Rasio modal sendiri terhadap pinjaman yang berisiko digunakan untuk menggambarkan kemampuan modal perusahaan dalam mengatasi pinjaman berisiko yang diberikan oleh perusahaan. Pinjaman berisiko sendiri didapatkan dari hasil perhitungan keseluruhan pinjaman yang dimiliki oleh perusahaan kemudian ditambahkan dengan besarnya jumlah piutang yang didapat. Untuk menganalisis rasio modal sendiri terhadap pinjaman yang berisiko dapat menggunakan rumus:

Rasio Modal Sendiri terhadap Pinjaman Berisiko $=\frac{\text { Modal Sendiri }}{\text { Pinjaman diberikan berisiko }} \times 100 \%$

Berikut merupakan hasil analisis rasio modal sendiri terhadap pinjaman diberikan yang berisiko pada Koperasi Multi Kharisma Banyuasin:

1. Tahun 2014

$$
\begin{aligned}
& \frac{10.188 .087 .112,64}{8.514 .383 .564,35} \times 100 \% \\
& =1,196=119,6 \%
\end{aligned}
$$

2. Tahun 2015

$$
\begin{aligned}
& \frac{8.284 .167 .715,14}{8.702 .488 .414,35} \times 100 \% \\
& =0,9519=95,19 \%
\end{aligned}
$$

3. Tahun 2016

$$
\begin{aligned}
& \frac{10.066 .936 .963,34}{8.664 .455 .942,92} \times 100 \% \\
& =1,161=116,1 \%
\end{aligned}
$$

4. Tahun 2017

$$
\begin{aligned}
& \frac{13.141 .223 .827,31}{9.574 .106 .642,92} \times 100 \% \\
& =1.372=137,2 \%
\end{aligned}
$$

5. Tahun 2018

$$
\begin{aligned}
& \frac{13.793 .374 .554,08}{9.968 .760 .242,92} \times 100 \% \\
& =1,383=138,3 \%
\end{aligned}
$$


Berdasarkan hasil analisis diatas dapat dilihat bahwa rasio modal sendiri terhadap pinjaman diberikan yang berisiko pada Koperasi Multi Kharisma Banyuasin selama tahun 2014-2018 adalah sebagai berikut :

1. Pada tahun 2014 rasio modal sendiri terhadap pinjaman beresiko yang diberikan mendapatkan angka rasio sebesar $119,6 \%$ yang diperoleh dari perhitungan modal sendiri sebesar $\mathrm{Rp} 10.188 .087 .112,64$ dengan total pinjaman diberikan yang berisiko sebesar $\mathrm{Rp} 8.514 .383 .564,35$. Hal ini berarti setiap 1 rupiah pinjaman berisiko dapat dijamin oleh modal sendiri sebesar 1,196 rupiah atau 1,196: 1 antara modal sendiri dan pinjaman beresiko.

2. Pada tahun 2015 rasio modal sendiri terhadap pinjaman berisiko koperasi mengalami penurunan sebesar $24,41 \%$ dari $119,6 \%$ menjadi $95,19 \%$ yang di peroleh dari perhitungan modal sendiri sebesar Rp 8.284.167.715,14 dengan total pinjaman beresiko sebesar Rp 8.702.488.414,35. Hal ini berarti setiap 1 rupiah pinjaman beresiko dapat dijamin oleh modal sendiri sebesar 0,9519 rupiah atau 1 : 0,9519 antara modal sendiri dan pinjaman diberikan yang berisiko.

3. Pada tahun 2016 rasio modal sendiri terhadap pinjaman berisiko koperasi mengalami peningkatan yaitu sebesar 20,91\% dari 95,19\% menjadi sebesar $116,1 \%$ yang diperoleh dari perhitungan modal sendiri yaitu sebesar $\mathrm{Rp}$ 10.066.936.963,34 dengan pinjaman diberikan yang berisiko sebesar $\mathrm{Rp}$ 8.664.455.942,92. Hal ini berarti setiap 1 rupiah pinjaman berisiko dapat dijamin oleh modal sendiri sebesar 1,161 rupiah atau 1,161:1 antara modal sendiri dan pinjaman berisiko.

4. Pada tahun 2017 rasio modal sendiri terhadap total aset koperasi kembali mengalami peningkatan yaitu sebesar $21,1 \%$ dari $116,1 \%$ menjadi $137,2 \%$ yang diperoleh dari perhitungan modal sendiri yaitu $R p$ 13.141.223.827,31 dengan total pinjaman berisiko sebesar Rp 9.574.106.642,92. Hal ini berarti setiap 1 rupiah pinjaman beresiko dapat dijamin oleh modal sendiri sebesar 1,372 rupiah atau 1,372:1 antara modal sendiri dan total pinjaman beresiko.

5. Pada tahun 2018 rasio modal sendiri terhadap pinjaman diberikan yang berisiko mendapatkan angka rasio $138,3 \%$ yang diperoleh dari perhitungan modal sendiri sebesar Rp 13.793.374.554,08 dengan total pinjaman beresiko sebesar Rp 9.968.760.242,92. Hal ini berarti setiap 1 rupiah pinjaman berisiko dapat dijamin oleh modal sendiri sebesar 1,383 rupiah atau 1,383:1 antara modal sendiri dan pinjaman diberikan yang berisiko.

Berikut adalah standar penetapan standar skor rasio modal sendiri terhadap pinjaman di berikan yang berisiko:

\section{Tabel 3}

Standar Penetapan Standar Skor Rasio Modal Sendiri terhadap Pinjaman di berikan yang Berisiko

\begin{tabular}{|c|c|c|c|}
\hline $\begin{array}{c}\text { Rasio Modal } \\
\%\end{array}$ & Nilai & $\begin{array}{c}\text { Bobot } \\
\%\end{array}$ & Skor \\
\hline
\end{tabular}




\begin{tabular}{|c|c|c|c|}
\hline$\leq 0$ & 0 & 6 & 0 \\
$0<\mathrm{x}<10$ & 10 & 6 & 0.6 \\
$10<\mathrm{x}<20$ & 20 & 6 & 1.2 \\
$20<\mathrm{x}<30$ & 30 & 6 & 1.8 \\
$30<\mathrm{x}<40$ & 40 & 6 & 2.4 \\
$40<\mathrm{x}<50$ & 50 & 6 & 3.0 \\
$50<\mathrm{x}<60$ & 60 & 6 & 3.6 \\
$60<\mathrm{x}<70$ & 70 & 6 & 4.2 \\
$70<\mathrm{x}<80$ & 80 & 6 & 4.8 \\
$80<\mathrm{x}<90$ & 90 & 6 & 5.4 \\
$90<\mathrm{x}<100$ & 100 & 6 & 6.0 \\
\hline
\end{tabular}

Sumber : PERMENKUKMNO.20/PER/M.KUKM/XI/2008

Berdasarkan hasil analisis rasio modal sendiri terhadap total pinjaman diberikan yang berisiko koperasi apabila dilihat dari perkembangannya dari tahun 2014-2018, rasio modal sendiri terhadap pinjaman beresiko tertinggi berada pada tahun 2018 dengan perolehan angka rasio sebesar 181,3\%, dan secara keseluruhan rata-rata rasio modal sendiri tehadap pinjaman diberikan yang berisiko selama lima tahun terakhir mendapatkan angka rasio yang berkisar lebih dari $90 \%$. Hal ini sesuai dengan standar perhitungan rasio modal sendiri terhadap pinjaman diberikan yang berisiko dimana rasio modal sendiri terhadap pinjaman yang beresiko mendapatkan hasil perhitungan lebih dari $90 \%$ maka akan mendapatkan nilai 100 dan memperoleh angka skor 6,00 sebagai nilai skor akhir nya.

\section{Analisis Rasio Kecukupan Modal Sendiri terhadap Aset Tertimbang Menurut Risiko (ATMR).}

Rasio modal sendiri terhadap aset tertimbang menurut risiko digunakan untuk menggambarkan kemampuan modal perusahaan dalam memenuhi total aset tertimbang menurut risiko yang dimilkinya. Modal tertimbang adalah jumlah dari hasil kali setiap komponen modal KSP/USP koperasi yang terdapat pada Neraca dengan bobot pengakuan risiko. ATMR adalah jumlah dari hasil kali setiap komponen aset KSP dan USP koperasi yang terdapat pada Neraca dengan bobot pengakuan risiko. Untuk menganalisis rasio modal sendiri terhadap aset tertimbang menurut risiko dapat menggunakan rumus:

$$
\text { Rasio Kecukupan Modal Sendiri }=\frac{\text { Modal tertimbang }}{\text { ATMR }} \times 100 \%
$$

Berikut merupakan hasil analisis rasio modal sendiri terhadap aktiva tertimbang menurut resiko pada Koperasi Multi Kharisma Banyuasin:

1. Tahun 2014

$$
\begin{aligned}
& \frac{7.816 .059 .965,40}{4.416 .937 .048,35} \times 100 \% \\
& =1,769=176,9 \%
\end{aligned}
$$

2. Tahun 2015

$$
\begin{aligned}
& \begin{array}{l}
8.191 .398 .632,19 \\
3.733 .970 .405,63
\end{array} \times 100 \% \\
& =2,193=219,3 \%
\end{aligned}
$$


3. Tahun 2016

$$
\begin{aligned}
& \frac{9.960 .457 .965,30}{5.606 .129 .510,55} \times 100 \% \\
& =1,776=177,6 \%
\end{aligned}
$$

4. Tahun 2017

$$
\begin{aligned}
& \frac{10.054 .756 .899,67}{5.763 .542 .959,96} \times 100 \% \\
& =1,744=174,4 \%
\end{aligned}
$$

5. Tahun 2018

$$
\begin{aligned}
& \frac{10.384 .054 .447,78}{6.140 .183 .572,46} \times 100 \% \\
& =1,691=169,1 \%
\end{aligned}
$$

Berdasarkan hasil analisis diatas dapat dilihat bahwa rasio kecukupan modal sendiri pada Koperasi Multi Kharisma Banyuasin tahun 2014-2018 adalah sebagai berikut :

1. Pada tahun 2014 rasio kecukupan modal sendiri terhadap aset tertimbang menurut risiko di dapati hasil yaitu sebesar 176,9\% yang diperoleh dari perhitungan modal tertimbang yaitu $\mathrm{Rp} 7.816 .059 .965,40$ dengan perhitungan aset tertimbang menurut risiko (ATMR) yaitu sebesar Rp 4.416.937.048,35. Hal ini berarti setiap 1 rupiah aset tertimbang dapat dijamin oleh modal sendiri sebesar 1,769 rupiah atau 1,769: 1 antara kecukupan modal sendiri dan aset tertimbang menurut risiko.

2. Pada tahun 2015 rasio kecukupan modal sendiri mengalami peningkatan sebesar $42,4 \%$ dari $176,9 \%$ menjadi sebesar $219,3 \%$. Hal ini dikarenakan total kecukupan modal sendiri mengalami peningkatan dari tahun sebelumnya. Angka rasio ini diperoleh dari hasil perhitungan modal sendiri sebesar $\mathrm{Rp}$ 8.191.398.632,19 terhadap aset tertimbang menurut risiko sebesar $\mathrm{Rp}$ 3.733.970.405,63. Hal ini berarti setiap 1 rupiah total aset tertimbang menurut risiko dapat dijamin oleh kecukupan modal sendiri sebesar 2,193 rupiah atau 2,193 : 1 antara kecukupan modal sendiri dan total aset tertimbang menurut risiko.

3. Pada tahun 2016 rasio kecukupan modal sendiri mengalami penurunan yaitu sebesar $41,7 \%$ dari $219,3 \%$ menjadi sebesar $177,6 \%$ yang di peroleh dari perhitungan modal sendiri yaitu sebesar Rp 9.960.457.965,30 dengan aset tertimbang menurut risiko yaitu $\mathrm{Rp} 5.606 .129 .510,55$. Hal ini berarti setiap 1 rupiah aktiva tertimbang menurut resiko dapat dijamin oleh kecukupan modal sendiri sebesar 177,6 rupiah atau 177,6 : 1 antara modal sendiri dan total aset tertimbang menurut risiko.

4. Pada tahun 2017 rasio modal sendiri terhadap aset tertimbang menurut risiko kembali mengalami penurunan yaitu sebesar $3,2 \%$ dari $177,6 \%$ menjadi $174,4 \%$ yang diperoleh dari perhitungan modal sendiri yaitu sebesar Rp 10.054.756.889,67 dengan total aset tertimbang menurut risiko sebesar $\mathrm{Rp}$ 
5.763.542.259,96. Hal ini berarti setiap 1 rupiah total aset tertimbang menurut risiko dapat dijamin oleh modal sendiri sebesar 1,744 rupiah atau 1,744:1 antara modal sendiri dan total aset tertimbang menurut risiko.

5. Pada tahun 2018 rasio modal sendiri terhadap total aset tertimbang menurut risiko mengalami penurunan kembali yaitu sebesar $5,3 \%$ dari $174,4 \%$ menjadi $169,1 \%$ yang diperoleh dari perhitungan modal sendiri sebesar $\mathrm{Rp}$ 10.384.054.447,78 dengan total aset tertimbang menurut risiko sebesar $\mathrm{Rp}$ 6.140.183.572,46. Hal ini berarti setiap 1 rupiah aset tertimbang menurut risiko dapat dijamin oleh modal sendiri sebesar 1,691 rupiah atau 1,691: 1 antara modal sendiri dan total aset tertimbang menurut risiko.

Berikut adalah standar penetapan rasio modal sendiri terhadap aset tertimbang menurut risiko :

Tabel 4

Standar Penetapan Rasio Modal Sendiri terhadap Aset Tertimbang Menurut Risiko

\begin{tabular}{|c|c|c|c|}
\hline $\begin{array}{c}\text { Rasio Modal } \\
(\boldsymbol{\%})\end{array}$ & Nilai & $\begin{array}{c}\text { Bobot } \\
(\boldsymbol{\%})\end{array}$ & Skor \\
\hline$\leq 4$ & 0 & 3 & 0 \\
$4<\mathrm{x} \leq 6$ & 50 & 3 & 1.50 \\
$6<\mathrm{x} \leq 8$ & 75 & 3 & 2.25 \\
$>8$ & 100 & 3 & 3.00 \\
\hline
\end{tabular}

Sumber : PERMENKUKMNO.20/PER/M.KUKM/XI/2008

Berdasarkan hasil analisis rasio kecukupan modal sendiri apabila dilihat dari perkembangannya dari tahun 2014-2018, rasio kecukupan modal sendiri tertinggi berada pada tahun 2015 dengan perolehan angka rasio sebesar $219,3 \%$, dan secara keseluruhan rata-rata rasio selama lima tahun terakhir mendapatkan angka rasio lebih dari $8 \%$. Hal ini sesuai dengan standar perhitungan rasio kecukupan modal sendiri dimana rasio modal yang mendapatkan hasil perhitungan lebih dari $8 \%$ maka akan mendapatkan nilai 100 dan memperoleh angka skor 3,00 sebagai nilai skor akhir nya.

\section{H. PEMBAHASAN}

\section{Rasio Modal Sendiri terhadap Total Aset}

Rasio modal sendiri terhadap total aset pada Koperasi Multi Kharisma Banyuasin periode tahun 2014 sampai dengan tahun 2018 berturut-turut sebesar $77.86 \%$ atau $0.7786 \mathrm{kali}, 57.38 \%$ atau $0.5738 \mathrm{kali}, 70.43 \%$ atau $0.7043 \mathrm{kali}, 87.51 \%$ atau 0.8751 kali dan $88.82 \%$ atau 0,8882 kali. Hal ini menunjukkan bahwa total aset Koperasi Multi Kharisma Banyuasin setiap sebesar Rp 1,00 dapat dijamin oleh modal sendiri yaitu sebesar Rp 0.7786, Rp 0.5738, Rp 0.7043, Rp 0.8751 dan sebesar Rp 0.8882 . Sehingga rata-rata rasio modal sendiri terhadap total aset dari tahun 2014 sampai dengan tahun 2018 adalah $76.4 \%$ atau 7,640 kali. Karena rasio modal sendiri terhadap total aset lebih dari $20 \%$ maka akan mendapatkan nilai 100 dan rasio modal sendiri terhadap total aset mendapatkan skor 6,00 sebagaimana tercantum dalam peraturan menteri Negara Koperasi dan Usaha Kecil dan Menengah No.20/PER/M.KUKM/XI/2008. Hal ini berarti Koperasi Multi Kharisma Banyuasin 
mempunyai modal yang cukup untuk menjamin seluruh total asetnya apabila suatu waktu perusahaan mengalami pailit dan harus dilikuidasi.

\section{Rasio Modal Sendiri terhadap Pinjaman diberikan yang Berisiko}

Rasio modal sendiri terhadap pinjaman diberikan yang berisiko pada Koperasi Multi Kharisma Banyuasin periode tahun 2014 sampai dengan tahun 2018 berturutturut sebesar $119.6 \%$ atau 1.196 kali, $95.19 \%$ atau 0.9519 kali, $116.1 \%$ atau 1.161 kali, $137.2 \%$ atau 1.372 kali dan $138.3 \%$ atau 1.383 kali. Hal ini menunjukkan bahwa setiap pinjaman berisiko yang diberikan Koperasi Multi Kharisma Banyuasin setiap sebesar Rp 1,00 dapat dijamin oleh modal sendiri yaitu sebesar Rp 1.196, Rp 0.9519, Rp 1.161, Rp 1.372 dan sebesar Rp 1.383. Sehingga rata-rata rasio modal sendiri terhadap pinjaman diberikan yang berisiko dari tahun 2014 sampai dengan tahun 2018 adalah $121.3 \%$ atau 1,213 kali. Karena rasio modal sendiri terhadap total aset lebih dari 90\% maka akan mendapatkan nilai 100 dan rasio modal sendiri terhadap total aset mendapatkan skor 6,00 sebagaimana tercantum dalam peraturan menteri Negara Koperasi dan Usaha Kecil dan Menengah No.20/PER/M.KUKM/XI/2008. Hal ini berarti Koperasi Multi Kharisma Banyuasin mempunyai modal yang cukup untuk menjamin seluruh total pinjaman yang berisiko yng dimiliki koperasi apabila suatu waktu pinjaman yang diberikan oleh koperasi tidak dapat dibayarkan oleh para peminjam koperasi.

\section{Rasio Kecukupan Modal Sendiri}

Rasio modal sendiri pada Koperasi Multi Kharisma Banyuasin periode tahun 2014 sampai dengan tahun 2018 berturut-turut sebesar $176.9 \%$ atau 1.769 kali, $219.3 \%$ atau 2.193 kali, $177.6 \%$ atau 1.776 kali, $174.4 \%$ atau 1.744 kali dan $169.1 \%$ atau 1,691 kali. Hal ini menunjukkan bahwa total aset tertimbang menurut risiko pada Koperasi Multi Kharisma Banyuasin setiap sebesar $\mathrm{Rp} 1,00$ dapat dijamin oleh kecukupan modal sendiri sebesar $\mathrm{Rp} 1.769$, Rp 2.193, Rp 1.776, Rp 1.744 dan sebesar $\mathrm{Rp}$ 1.691. Sehingga rata-rata rasio modal sendiri terhadap total aset dari tahun 2014 sampai dengan tahun 2018 adalah $183.4 \%$ atau 1,834 kali. Karena rasio kecukupan modal sendiri lebih dari $8 \%$ maka akan mendapatkan nilai 100 dan rasio kecukupan modal sendiri mendapatkan skor 3,00 sebagaimana tercantum dalam peraturan menteri Negara Koperasi dan Usaha Kecil dan Menengah No.20/PER/M.KUKM/XI/2008. Hal ini berarti Koperasi Multi Kharisma Banyuasin mempunyai modal yang cukup untuk menjamin seluruh total aset tertimbang menurut risiko apabila suatu waktu aset perusahaan harus dilikuidasi.

\section{Rasio Permodalan Koperasi Karya Mukti Kota Muntok}

Rasio Permodalan Koperasi Multi Kharisma Banyuasin adalah sebagai berikut :

Tabel 5

Rekapitulasi Hasil Perhitungan Rasio Permodalan Koperasi Multi Kharisma Banyuasin Tahun 2014-2018

\begin{tabular}{|c|c|c|c|c|c|c|}
\hline \multirow{2}{*}{ No } & Keterangan & \multicolumn{5}{|c|}{ Tahun(\%) } \\
\cline { 3 - 7 } & & 2014 & $\mathbf{2 0 1 5}$ & $\mathbf{2 0 1 6}$ & $\mathbf{2 0 1 7}$ & 2018 \\
\hline
\end{tabular}




\begin{tabular}{|c|l|c|c|c|c|c|}
\hline 1 & Rasio Modal sendiri terhadap Total Aset & $77,86 \%$ & $57,38 \%$ & $70,43 \%$ & $87,51 \%$ & $88,82 \%$ \\
\hline 2 & Rasio Modal Sendiri terhadap Pinjaman Beresiko & $119,6 \%$ & $95,19 \%$ & $116,1 \%$ & $137,2 \%$ & $138,3 \%$ \\
\hline 3 & Rasio Kecukupan Modal Sendiri & $176,9 \%$ & $219,3 \%$ & $177,6 \%$ & $174,4 \%$ & $169,1 \%$ \\
\hline
\end{tabular}

Sumber : Data diolah oleh penulis (2018)

Dari data diatas dapat diketahui rasio permodalan pada Koperasi Multi Kharisma Banyuasin dari tahun 2014-2018. Untuk rasio modal sendiri terhadap total aset tertinggi diperoleh pada tahun 2018 yaitu sebesar 88,2\%. Untuk rasio modal sendiri terhadap pinjaman beresiko tertinggi juga diperoleh pada tahun 2018 yaitu sebesar $138,3 \%$. Sedangkan untuk rasio kecukupan modal sendiri tertinggi diperoleh pada tahun 2015 yaitu sebesar $219,3 \%$.

Tabel 6

Rekapitulasi Standar dan Kategori Rasio Permodalan Koperasi Multi Kharisma Banyuasin Tahun 2014-2018

\begin{tabular}{|l|l|c|c|c|}
\hline No & Rasio & Skor Rata-rata \% & Standar Rasio \% & Bobot \% \\
\hline 1 & $\begin{array}{l}\text { Rasio Modal Sendiri } \\
\text { terhadap Total Aset }\end{array}$ & $76,4 \%$ & $\geq 15$ & 6 \\
\hline 2 & $\begin{array}{l}\text { Rasio Modal Sendiri } \\
\text { terhadap Pinjaman } \\
\text { Berisiko }\end{array}$ & $121,3 \%$ & $\geq 90$ & 6 \\
\hline 3 & $\begin{array}{l}\text { Rasio Kecukupan Modal } \\
\text { Sendiri }\end{array}$ & $183,5 \%$ & 3 & 15 \\
\hline \multicolumn{3}{|c|}{ TOTAL } & SEHAT \\
\hline
\end{tabular}

Tabel 7

Penetapan Predikat Tingkat Kesehatan Koperasi Aspek Permodalan

\begin{tabular}{|c|c|}
\hline Skor & Kategori \\
\hline$\leq 0$ & Sangat tidak sehat \\
\hline $0<\mathrm{X} \leq 5$ & Tidak sehat \\
\hline $5<\mathrm{X} \leq 10$ & Kurang sehat \\
\hline $10<\mathrm{X} \leq 15$ & Cukup sehat \\
\hline$\geq 15$ & Sehat \\
\hline Sumber : PERMENKUKMNO.20/PER/M.KUKM/XI/2008
\end{tabular}

Berdasarkan hasil analisis terhadap laporan keuangan dan kinerja aspek permodalan pada Koperasi Multi Kharisma Banyuasin dari tahun 2014-2018, maka aspek permodalan pada Koperasi Multi Kharisma Banyuasin dari tahun 2014-2018 berada dalam kategori sehat. Hal ini dikarenakan aspek permodalan pada Koperasi Multi Kharisma Banyuasin mendapatkan angka 15,00 sebagai skor akhir dari keseluruhan rasio permodalan yang telah dianalisis. Skor ini didapatkan dari hasil penjumlahan keseluruhan skor yang telah di dapat oleh rasio yang telah dianalisis, dimana rasio modal sendiri terhadap total aset mendapatakan skor 6,00, rasio modal sendiri terhadap pinjaman diberikan yang berisiko mendapatkan skor 6,00 dan rasio kecukupan modal sendiri mendapatkan skor 3,00 sehingga di dapat total keseluruhan skor yaitu 15,00 dimana aspek permodalan koperasi yang 
mendapatkan nilai skor $\geq 15$ dikategorikan dalam kategori sehat sebagaimana tercantum pada peraturan menteri negara Koperasi dan Usaha Kecil dan Menengah No.20/PER/K.KUKM/XI/2008.

\section{KESIMPULAN DAN SARAN}

\section{Kesimpulan}

Berdasarkan hasil penelitian dan pembahasan pada aspek permodalan di Koperasi Multi Kharisma Banyuasin, maka dapat disimpulkan sebagai berikut :

a) Berdasarkan hasil rasio modal sendiri terhadap total aset pada Koperasi Multi Kharisma Banyuasin bahwa rata-rata rasio modal sendiri terhadap total aset dari tahun 2014 sampai dengan tahun 2018 adalah $76.4 \%$ atau 7.640 kali sehingga rasio modal sendiri terhadap total aset mendapatkan nilai 6,00 sebagai angka skor akhirnya. Hal ini sesuai dengan Peraturan Menteri Negara Koperasi dan Usaha Kecil dan Menengah Republik Indonesia No.20/PER/M.KUKM/XI/2008.

b) Berdasarkan hasil rasio modal sendiri terhadap total pinjaman diberikan yang berisiko pada Koperasi Multi Kharisma Banyuasin bahwa rata-rata rasio modal sendiri terhadap pinjaman diberikan yang berisiko dari tahun 2014 sampai dengan tahun 2018 adalah $121.3 \%$ atau 1.213 kali sehingga rasio modal sendiri terhadap total pinjaman diberikan yang berisiko mendapatkan nilai 6,00 sebagai angka skor akhirnya. Hal ini sesuai dengan Peraturan Menteri Negara Koperasi dan Usaha Kecil dan Menengah Republik Indonesia No.20/PER/M.KUKM/XI/2008.

c) Berdasarkan hasil rasio kecukupan modal sendiri pada Koperasi Multi Kharisma Banyuasin bahwa rata-rata rasio kecukupan modal sendiri dari tahun 2014 sampai dengan tahun 2018 adalah $183.4 \%$ atau 1.834 kali, sehingga rasio kecukupan modal sendiri terhadap mendapatkan nilai 3,00 sebagai angka skor akhirnya. Hal ini sesuai dengan Peraturan Menteri Negara Koperasi dan Usaha Kecil dan Menengah Republik Indonesia No.20/PER/M.KUKM/XI/2008.

d) Berdasarkan hasil analisis terhadap laporan keuangan dan kinerja aspek permodalan pada Koperasi Multi Kharisma Banyuasin dari tahun 2014-2018, maka aspek permodalan pada Koperasi Multi Kharisma Banyuasin dari tahun 2014-2018 berada dalam kategori sehat. Hal ini dikarenakan aspek permodalan pada Koperasi Multi Kharisma Banyuasin mendapatkan angka 15,00 sebagai skor akhir dari keseluruhan rasio permodalan yang telah dianalisis. Skor ini di dapat dari hasil penjumlahan keseluruhan skor yang telah di dapat oleh rasio yang telah dianalisis, dimana rasio modal sendiri terhadap total aset mendapatkan skor 6,00 , rasio modal sendiri terhadap pinjaman diberikan yang berisiko mendapatkan skor 6,00 dan rasio kecukupan modal sendiri mendapatakan skor 3,00 sehingga di dapat total keseluruhan skor yaitu 15,00 dimana aspek permodalan koperasi yang mendapatkan nilai skor $\geq 15$ dikategorikan dalam kategori sehat sebagaimana tercantum pada Peraturan Menteri Negara Koperasi dan Usaha Kecil dan Menengah No.20/PER/K.KUKM/XI/2008.

\section{Saran}


Berdasarkan kesimpulan diatas, maka penulis memberikan saran bagi Koperasi Multi Kharisma Banyuasin :

a) Untuk Rasio Modal Sendiri terhadap Total Aset, disarankan agar tetap mempertahankan dan menjaga keseluruhan nilai modal koperasi agar keseluruhan nilai modal koperasi tetap lebih besar dari jumlah keseluruhan total aset yang dimilikinya.

b) Untuk Rasio Modal Sendiri terhadap Pinjaman diberikan yang Berisiko, disarankan agar koperasi memberlakukan standar tertentu sebelum memberikan pinjaman kepada pihak lain dengan jumlah yang besar, sehingga koperasi dapat meminimalkan risiko kerugian apabila suatu waktu pinjaman yang diberikan tidak dapat dikembalikan oleh peminjamnya.

c) Untuk Rasio Kecukupan Modal Sendiri, disarankan agar tetap mempertahankan jumlah keseluruhan modal tertimbang agar tetap lebih besar dari jumlah aset tertimbangnya. Sehingga modal yang dimiliki koperasi akan dapat menutupi dan mencukupi keseluruhan pembayaran apabila pada suatu waktu koperasi mengalami pailit dan harus dilikuidasi.

d) Berdasarkan hasil analisis dan pembahasan yang dilakukan terhadap aspek permodalan pada Koperasi Multi Kharisma Banyuasin, disarankan untuk mempertahankan rasio permodalannya agar tetap berada dalam kategori sehat sebagaimana tercantum dalam Peraturan Menteri Negara Koperasi Usaha Kecil dan Menengah No. 20/PER/M.KUKM/XI/2008.

\section{DAFTAR PUSTAKA}

Fahmi, Irham 2012. Analisis Kinerja Keuangan. Penerbit : Alfabeta. Bandung.

Hendri. 2014. Analisa Laporan Keuangan Untuk Menilai Kinerja Keuangan Koperasi Pegawai Negeri Pagar Bunga Ngulak Kabupaten Musi Banyuasin. Skripsi Fakultas Ekonomi Universitas PGRI Palembang (tidak untuk dipublikasikan).

Hery. 2015. Analisis Laporan Keuangan. Penerbit: CAPS. Yogyakarta.

Horne, Van. 2012. Financial Management and Policy, Twelve Edition.Pravtic Hall International Inc. London.

IAI. 2013. Standar Akuntansi Keuangan Tanpa Entitas Publik (SAK ETAP).Penerbit : IAI. Jakarta.

IAI Sumsel. 2012. Pengantar Akuntansi berbasis SAK ETAP. Penerbit : IAI. Palembang.

Jumingan. 2014. Analisis Laporan Keuangan. Penerbit : Bumi aksara. Jakarta.

Kasmir. 2014. Analisis Laporan Keuangan. Penerbit : PT Raja Grafindo Persada. Jakarta. 
Menteri Koperasi dan Usaha Kecil Menengah Republik Indonesia. 2008. Peraturan Menteri Koperasi dan Usaha Kecil Menengah No.20/PER/M.KUKM/XI/2008 tentang Pedoman Penilaian Koperasi Simpan Pinjam.

Menteri Koperasi dan Usaha Kecil Menengah Republik Indonesia. 2012. Peraturan Menteri Koperasi dan Usaha Kecil Menengah No.4/Per/M.KUKM/VII/2012 tentang Pedoman Umum Akuntansi Koperasi.

Munawir. 2014. Analisis Laporan Keuangan. Penerbit : Liberty. Yogyakarta.

Republik Indonesia. 1992. Undang-undang No. 25 tahun 1992 tentang Koperasi.

Sugiyono. 2015. Metode Penelitian. Penerbit : Alfabeta. Bandung.

Sjahrial, Dermawan. 2013. Analisis Laporan Keuangan. Penerbit : Mitra Wacana Media. Jakarta.

Turi, La Ode, 2014.Akuntansi Koperasi Suatu Tinjauan Konsep dan Aplikasinya, Penerbit : Unhalu Press. Kendari.

Warda, Novida. 2016. Analisis Kinerja Keuangan pada Koperasi Serba Usaha (KSU) Rejosari Kecamatan Tenayan Raya Kota Pekanbaru. E-Skripsi Fakultas Ekonomi Universitas Riau (tidak untuk dipublikasikan). 